\title{
A peste negra e as crenças religiosas: Conflito Ciência e Religião
}

\section{The Black Death and Religious Beliefs: Conflict between Science and Religion}

\author{
Andreia Carneiro-Carvalho, CITAB, Centro de Investigação e Tecnologias Agroambientais e \\ Biológicas, UTAD, Vila Real, Portugal (andreiamcc_500@hotmail.com) \\ Isilda Rodrigues, Universidade de Trás-os-Montes e Alto Douro (isilda@utad.pt)
}

\begin{abstract}
Resumo: A peste negra surgiu no século XIV na Europa, desencadeada pela bactéria Yersinia pestis transmitida pelas pulgas e rato-negro (Rattus rattus), sendo que a disseminação da doença ocorreu de forma rápida pelas rotas comerciais da seda e de especiarias. $\mathrm{O}$ alto índice de contágio e mortalidade levou muitas pessoas a apoiaremse na religião pois acreditavam, que através desta, se salvariam. À época, como o conhecimento científico, sobre este tipo de doenças era escasso, a população acreditava numa relação entre medicina e religião, considerando a peste negra como um castigo divino pelos pecados cometidos, criando deste modo um problema social grave. Ao longo da história, a Igreja Católica, alegadamente, poderá ter sido um fator limitante ao desenvolvimento do conhecimento científico. A ignorância e a fé desmedida terão conduzido a consequências graves, como a perseguição e assassinato de inocentes em nome da fé, sendo deste modo responsável por um elevado número de mortos na Idade Média ao incentivar a eliminação dos judeus na Europa, como uma necessidade de se redimirem pelos pecados.

Neste texto pretendemos apontar os principais contributos para o desenvolvimento do conhecimento sobre esta patologia bem como a sua relação com a religião, as teorias difundidas pela Igreja e a crença cega do povo nas mesmas, para alcançar o perdão de Deus. A Religião pode ser um entrave ao conhecimento científico, impedindo o avanço da Ciência, além de conduzir as pessoas a cometerem atitudes erróneas e perversas para alcançar os seus objetivos.
\end{abstract}

Palavras-chave: autoflagelação, peste bubónica, religião, rituais fúnebres.

\footnotetext{
Abstract: The black plague appeared in the $14^{\text {th }}$ century in Europe by the bacterium Yersinia pestis transmitted by fleas and black rat (Rattus rattus), moreover the spread of this disease was very quickly through silk and spices trade routes. The high rate of contagion and mortality led many people to rely on religion, because they believed it would save themselves. At the time, as scientific knowledge about this type of diseases was scarce, the population believed in a relationship between medicine and religion, considering the Black Death as a divine punishment for the
} 
sins creating a serious social problem. Over the course of history, the Catholic Church may have been a limiting factor in the development of scientific knowledge. Ignorance and unreasonable faith led to serious consequences, such as, the persecution and murder of innocents in the name of the faith, thus being responsible for a high number of deaths in the Middle Ages for encouraging the elimination of Jews in Europe, as a need for redeem themselves for their sins.

In this text, we intend to present the main contributions to the development of knowledge about this pathology as well its relationship with religion, the theories disseminated by the Church and the people's blind belief in them to obtain God's forgiveness. Religion can be an obstacle to scientific knowledge, preventing the advance of Science, in addition to leading people to commit wrong and perverse attitudes to achieve their objectives.

Keywords: bubonic plague, funebre rituals, religion, self-flagellation.

\section{Introdução}

A Peste Negra foi uma doença problemática que assolou o século XVI. Sendo transmitida ao ser humano pelas pulgas e ratos (rato-negro, Rattus rattus), propagou-se por todo o mundo, transformando-se em pandemia. Neste período ocorreram alguns fatores que favoreceram o desenvolvimento e propagação da mesma, tais como: a falta de condições de higiene e de saneamento básico, a sobrelotação das habitações e ausência de ventilação das mesmas e o convívio de perto das pessoas com os animais domésticos assim como os ratos que surgiam nas mesmas. Por outro lado, o transporte marítimo, bastante impulsionado na época, através da rota da seda e das especiarias, demonstrou como o mundo estava interligado ao ter proporcionado uma difusão rápida desta doença por todos os continentes. Durante muitos anos foi incutido no povo que a peste representava um castigo divino, devido aos pecados cometidos pelo homem na vida terrena, o que originou um aumento da adesão ao cristianismo para aplacarem a cólera de Deus. Esta situação levou os cristãos a seguirem diversas medidas religiosas de forma que quando alcançassem o purgatório pudessem salvar a sua alma e obter a vida eterna. As ideologias incutidas pela Igreja foram rapidamente assimiladas por grande número de pessoas, porque o medo e o pânico as dominavam seguindo fielmente a narrativa que os membros do clero difundiam e colocando-as em prática, o que teve graves consequências sociais.

O presente trabalho tem como objetivos apresentar a forma como a Peste Negra surgiu e se difundiu pelo mundo; refletir sobre o papel da religião no desenvolvimento do conhecimento médico da época; apresentar as teorias que surgiram relacionados com a origem da peste e por último inferir sobre o papel da religião no aparecimento de movimentos e ações com fins desastrosos para a sociedade. 
Propomo-nos, neste artigo, abordar a interpretação da pandemia da Peste Negra formulada pelos membros da Igreja, ao longo dos séculos XIV ao XVI, com base na análise de algumas obras como The Plague in Siena: Na Italian Chronicle (1348), Le Decameron (1558), La Cronica (1979) e La Muerte Negra. Desastres en la Europa (1989) e de uma narrativa descritiva e poética de autores que através da literatura procuraram retratar as situações ocorridas e os sentimentos vividos na época durante a fase crítica da Peste Negra, permitindo, deste modo, obter ensinamentos sobre esta patologia para futuras epidemias e pandemias.

\section{Peste Negra, origem e sintomas}

A história da Humanidade foi afetada por várias pandemias, destacando-se a Peste Negra, que é considerada uma das mais mortíferas. Foram dizimadas milhões de vidas em todo o mundo, como relatado por alguns autores (Sánchez-David, 2008):

“... A peste matou inúmeras pessoas e também vários animais domesticados pelo homem, como cães, cavalos, pássaros e até os próprios ratos que viviam nas paredes das casas"

Gottfried, 1989 in La muerte negra - Desastres en la Europa medieval

A designação Peste Negra estava relacionada com o aparecimento de hemorragias subcutâneas, que assumiam uma coloração escura quando a doença já estava avançada. $O$ doente após ser infetado demorava 3 a 7 dias a sucumbir, sendo que a maioria dos infetados acabavam por morrer (Simoni, 2007). Esta doença foi classificada como altamente contagiosa, porque a partir do momento que uma pessoa era infetada, rapidamente a transmitia às pessoas mais próximas, além de ter uma baixa probabilidade de sobrevivência (Pinto, 2020).

A Peste Negra ocorreu entre 1347-1722 e espalhou o medo na Idade Média e no Início da Idade Moderna. Foi causada pelo agente infecioso, a bactéria Yersinia pestis, originária da China e Ásia Central, que chegou à Europa pelos barcos utilizados nas rotas comerciais (de seda e especiarias), que atracavam nos portos de cidades costeiras da Europa, como Veneza e Génova, por onde se disseminou rapidamente matando metade da população europeia, como relatado no excerto seguinte (Silva et al., 2018):

"Eram tantas pessoas a morrer de dia e de noite, que acabavam por serem lançadas em valas e cobertas apenas com terra, quando ficavam superlotadas eram abertas mais para o mesmo fim. E eu, Agnolo di Tura, tive que ser eu mesmo a enterrar os meus cinco filhos (..). $O$ número de mortos era tão grande que se acreditava que tinha chegado o fim do mundo"

Di Tura, 1348, The Plague in Siena: An Italian Chronicle. 
Inicialmente o agente infecioso era transmitido aos humanos por ratos e pulgas que rapidamente o transmitiam devido à falta de cuidados de higiene e saneamento básico. À época a sociedade tinha o costume de descartar o lixo doméstico e as fezes pela janela o que constituía um problema grave que promovia a propagação da doença. Mais tarde passou a ser transmitida pelo ar nomeadamente por espirros, assim como por contacto com secreções e materiais contaminados, sendo que as bactérias tinham a capacidade de se infiltrar na pele do ser humano através de feridas (Sánchez-David, 2008; Miguelsanz \& Ramos, 2015). Só em 1980 quando os investigadores Poinar e Krause realizaram uma escavação onde foram encontrados 2400 corpos, foram efetuados estudos que determinaram que a peste negra era causada pelo bacilo Yersinia pestis (Callaway, 2011).

Existem três tipos clínicos de Peste Negra: a bubónica, a septicémica e a pneumónica, as quais diferem entre si pela forma de transmissão e pela severidade com que ataca o ser humano. A bubónica foi a mais retratada ao longo da história em gravuras como podemos observar na Fig. 1 (Escuer, 2020). Os principais sintomas eram febre acima dos $39^{\circ} \mathrm{C}$, delírio, aumento e inchaço dos gânglios linfáticos presentes nas axilas, no pescoço e nas virilhas e o aparecimento de manchas negras na pele resultantes de hemorragias. Contudo, o ser humano também podia infetar-se e disseminar a doença a partir de secreções (pus e sangue) ou através da tosse na forma pneumónica (Gurtner, 2020). Em relação à sintomatologia, era frequente ainda sofrerem calafrios, dores em todo o corpo, náuseas, dores de cabeça, vómitos e ataques de convulsão (Follador, 2016; Silva et al., 2018).

Giovanni Boccaccio (1313-1375), foi um importante escritor italiano, poeta e humanista do Renascimento, que na sua obra denominada Le Decameron apresentou os sintomas dos doentes com peste negra na época, referindo o seguinte:

Inicialmente os doentes apresentavam bubões na região da virilha ou nas axilas, sendo encontrados tanto em homens como mulheres, podendo alcançar o tamanho de um ovo ou de uma maçã. Mais tarde, quando a doença evoluiu começaram a surgir manchas negras espalhas pelo corpo, algumas pessoas apresentavam manchas de maior dimensão outras mais pequenas, mas em maior número, sendo o aparecimento destas manchas anúncio da inevitável morte.

Boccacio, 1558, Le Decameron, p. 90

Também Matteo Villani (1283-1363), um importante historiador e escritor italiano na sua obra Cronica descreveu com pormenor os sintomas da peste e facilidade de contágio por parte de quem cuidava dos doentes, escrevendo que: 
(...) a peste ataca homens e mulheres, independentemente da idade ou sexo, que começavam a cuspir sangue, alguns morriam de repente após dois ou três dias, enquanto que outros poderiam demorar um pouco mais de tempo a falecer. Quem cuidava do doente, era facilmente infetado por a mesma maleita, ficando doente rapidamente e acabavam por morrer; muitos inchava a virilha, e a muitos sob as axilas à direita e à esquerda, e a outros em outras partes do corpo podia-se encontrar um inchaço em qualquer parte do corpo do doente.

Villani (1979) in Cronica, p. 137 tradução Quírico, 2012.

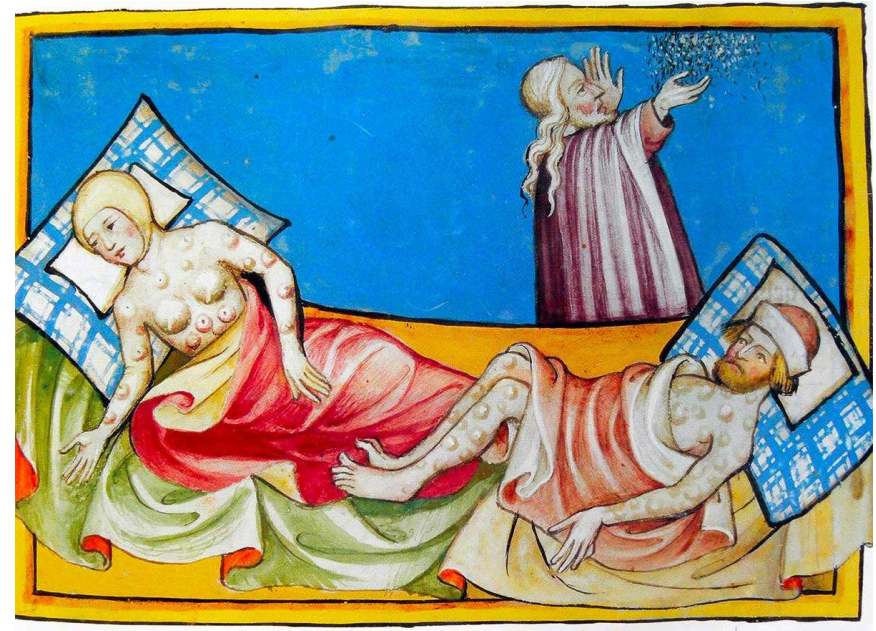

Figura 1- Doentes com Peste Negra (Toggenburg Bible circa1411 in Jones \& Nevel, 2016).

O mesmo autor acrescentou ainda que todos podiam ser infetados com a Peste Negra mesmo os membros da realeza. Assim, há registo que o rei de Castela Afonso XI (1311-1350) ficou infetado no acampamento militar decorrente de um cerco efetuado em Gibraltar e também diversos familiares do rei Pedro IV de Aragão (1319-1387) sucumbiram à peste, nomeadamente a sua filha, a mulher e uma sobrinha. A propagação da doença era muito elevada principalmente entre aqueles que tinham contacto direto com os doentes, como familiares, criados, padres e médicos, sendo estes mais vulneráveis (Follador, 2016).

No século XIV e XV acreditava-se que a peste era transmitida pelos cheiros pestilentos e devido ao contacto continuado dos médicos com os pacientes infetados, tendo sido criada uma vestimenta caraterística que se tornou um ícone desta patologia (Fig. 2). Consistia em uma capa comprida, um chapéu, luvas, um cabo longo para evitar tocar nos doentes e uma máscara em forma de bico semelhante ao bico de um pássaro, os quais eram impregnados com perfume e especiarias (Fig. 3) para funcionarem como um filtro do ar inspirado, evitando desta forma que fosse inalado o cheiro de podridão e acabassem infetados pela doença (Miguelsanz \& Ramos, 2015; Sílva et al., 2018). 


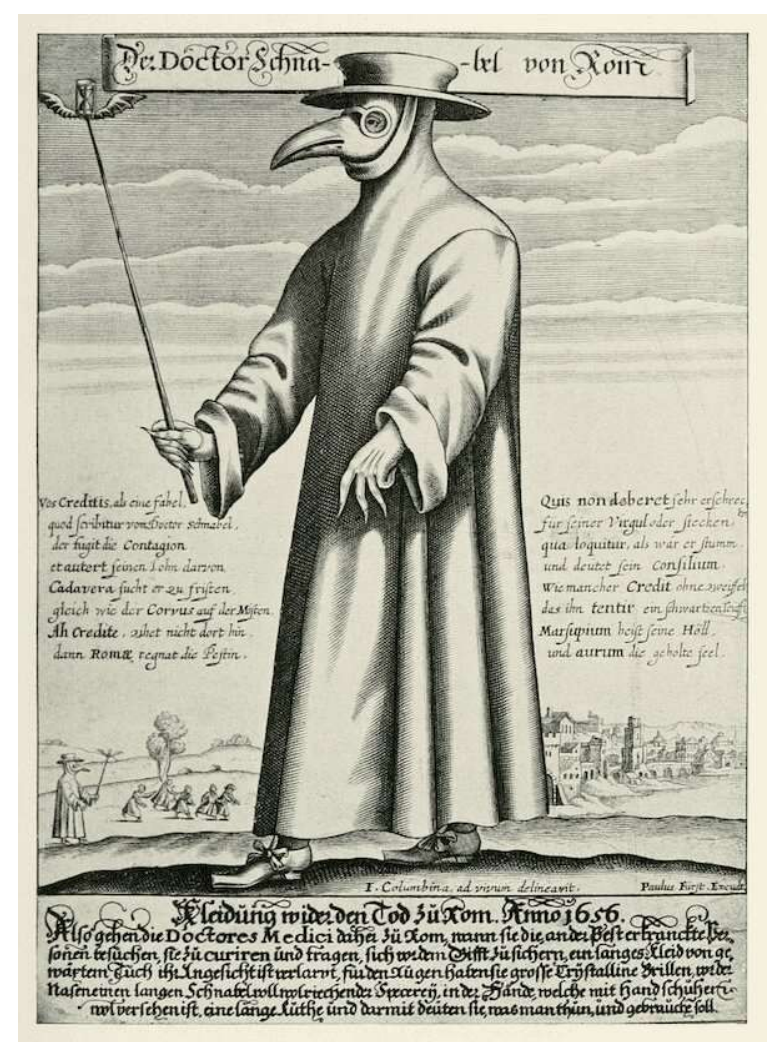

Figura 2 - Médico medieval no período da Peste Negra (Gusmão, 1984)

Alguns autores, nomeadamente Gusmão (1894) reafirmou a ideologia da origem da peste através do ar referindo que:

“(...) considerava que o ar era o elemento vital por onde respiramos o ar vital, com ele poluído, vai entrar pelos poros e ao ser respirado será poluido, podre, pelo que a prevenção passa por não se cansar, não correr, evitar irritar-se e a cólera, não rir, evitando movimentos que possam encher o peito de ar. (...)”

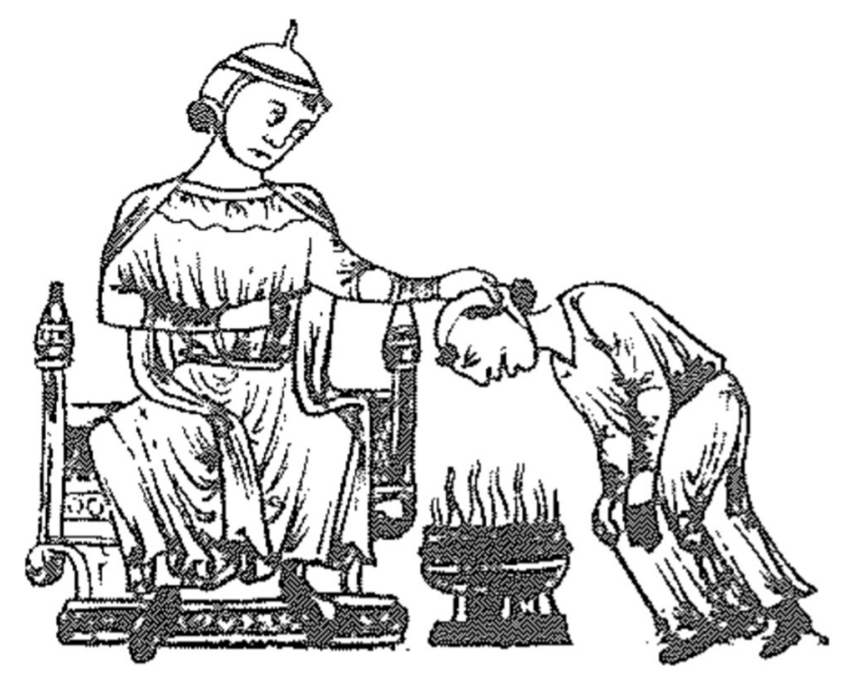

Figura 3 - Inalação de fumigações para combater odores pestilentos (Gusmão, 1984). 


\section{As crenças religiosas e o castigo divino}

$\mathrm{Na}$ Idade Média o conhecimento científico na área da medicina era muito limitado. Os conhecimentos médicos eram frequentemente relacionados com a religião, sendo as doenças frequentemente associadas a aspetos religiosos. Existia, por isso um certo conflito entre a Ciência e a Religião, na medida em que a Igreja proibia a realização de autópsias com o intuito de compreender melhor o corpo humano e, por outro lado, a medicina era muito praticada por membros do clero e por nobres, que "receitavam" chás e orações para evidenciarem a sua fé em Deus (Sílva et al., 2018). Durante este período as várias doenças que iam surgindo, como a Lepra, a Peste Negra e a epilepsia, iam sendo explicadas pelos pecados da carne, havendo por parte da Igreja um incentivo a atitudes discriminatórios, acabando os portadores destas doenças por serem ignorados, abandonados e excluídos da sociedade (Quírico, 2021). Como referiu, Jacme d'Agramont nas suas obras Pentateuco e no Libro de los Reyes que:

“(...) Não existe outro conselho que rezar humildemente, sem desconsiderar todos os conselhos médicos. que existia a mão de Deus sobre as pestes que ocorreram ao longo do tempo, sendo resultado conjunto da decisão divina e dos pecados humanos. (...)"

Jacme d'Agramont Regirnent, pp. 55-58 citado por Arrizabalaga Valbuena, 1991, p. 90

A tudo isto somou-se o medo perante o desconhecido, face ao elevado índice de contágio e à elevada mortalidade, onde a ideia do castigo divino foi incentivada (Fig. 4). Sob a ótica cristã, a doença fomentou a abordagem do pecado, da culpa, do arrependimento e da redenção, ressaltando o papel social da caridade. Em face à recorrência da peste, os homens entregaram-se mais dóceis a certas crenças e práticas cristãs (Bastos, 1997). As pessoas começaram a ver na Igreja um refúgio e uma esperança para ultrapassar a doença e salvarem as suas almas (Follador, 2016). $\mathrm{O}$ caos e aflição resultante da peste, como esta sendo resultado da fúria divina foi interpretado por muitos como uma premonição do fim do mundo (Quírico, 2021). A Peste Negra era vista do ponto de vista religioso como o resultado do pecado coletivo resultado das impurezas da sociedade (Bastos, 1997).

Na Idade Média houve o esforço por parte da religião de associar a pandemia a um castigo divino e os membros da Igreja esforçaram-se por incutir esta ideia nas pessoas através de discursos orais e escritos, ilustrações, rituais e cerimónias que realizavam. Do ponto de vista cristão a peste negra começou a incutir nas pessoas sentimentos de culpa, pecado, arrependimento e redenção, sendo essencial a relação do homem com Deus (Bastos, 1997). Esta perspetiva, pode ser 
facilmente observada na obra Decameron de Giovanni Bocaccio (1313-1375), onde este autor descreve alguns episódios que viveu em Florença durante o período da Peste Negra e onde é inegável a crença na teoria da cólera divina como justificação para a Peste Negra:

"A peste foi uma decisão divina dos céus sobre os homens, resultantes do desagrado de Deus, teve origem no Oriente e disseminou-se rapidamente para várias regiões, tendo sido mais afetado o Ocidente (...).

Boccaccio (1558) in Le Decameron p.100

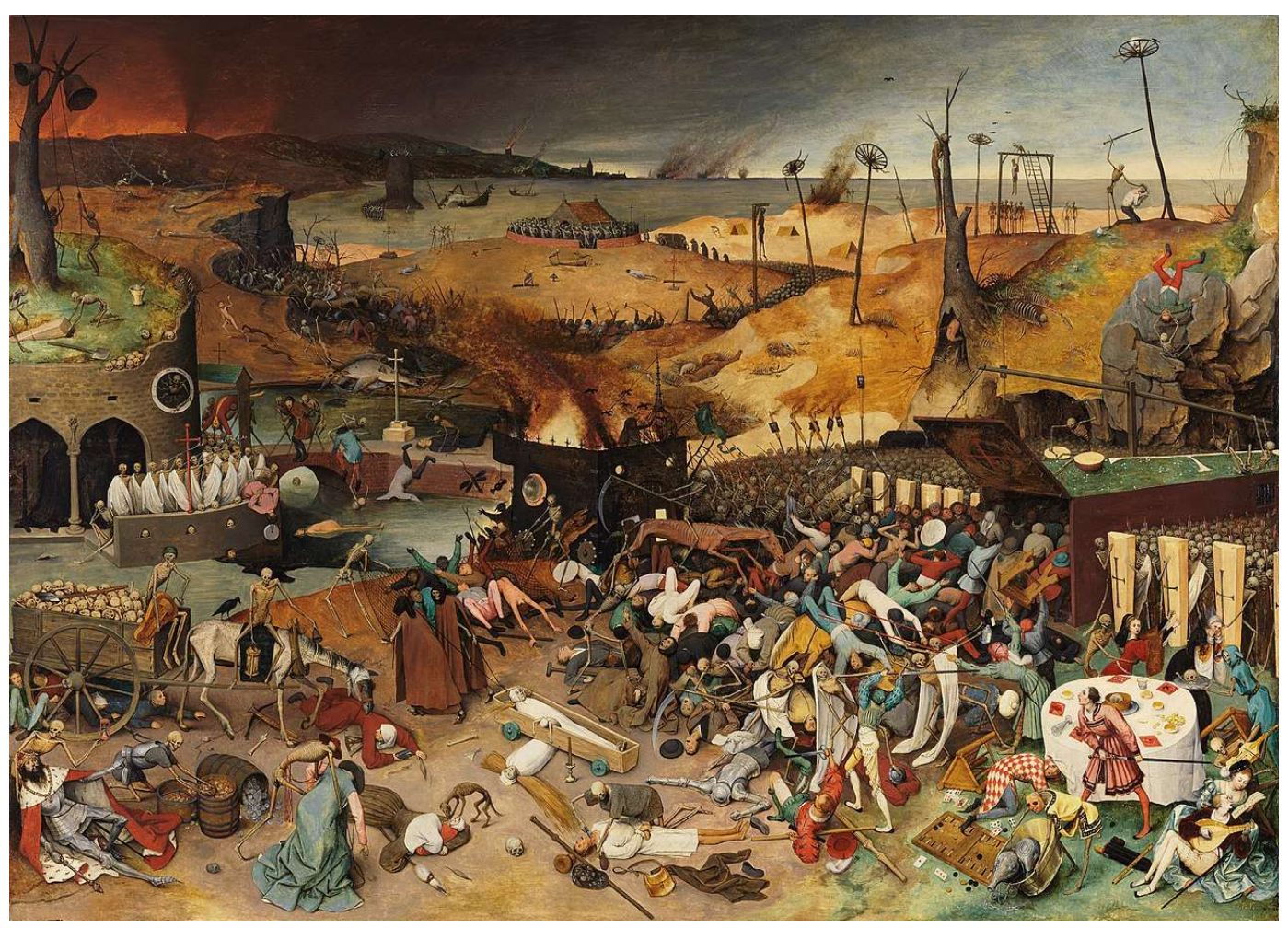

Figura 4 - O triunfo da morte, do pintor Pieter Bruegel, o Velho (1562) (Museu Del Prado, 2021).

Por seu lado, Delumeau (1978), referiu que a Igreja incutiu nas pessoas que a peste era um castigo divino, conseguindo durante vários séculos dominar a mentalidade dos cristãos através do medo da ira divina. A interferência da religião na sociedade chegou ao ponto de serem organizados eventos religiosos, como novenas e procissões para pedirem auxílio aos céus, nomeadamente, a São Sebastião, a São Roque e à Virgem Maria, consideradas figuras religiosas importantes capazes de conferir proteção contra a Peste Negra (Pinto, 2020; Marlow \& Rosa, 2021). Os religiosos da época associavam as flechas lançadas dos céus que se abateram sobre os homens com a peste, pelo que existia uma veneração pelos santos, como São Sebastião e São Roque que foram vítimas de ferimentos de 
flechas, os quais acabaram por ser considerados protetores contra esta doença (Bombini, 2020; Marlow \& Rosa, 2021). Tornou-se evidente o domínio da religião sobre a vida, a Igreja esforçou-se por controlar a forma de pensar das pessoas, associando tudo ao sobrenatural, ao divino, ao sacramento e à bíblia, impregnando ao extremo a religião no quotidiano dos fiéis (Bastos, 1997).

A elevada mortalidade que se verificava na época ajudava a corroborar estas teorias religiosas, acreditando os cristãos que ninguém parecia escapar ileso do poder punitivo de Deus, que exercia o seu castigo e justiça no mundo (Marlow e Rose, 2021).

Perante estas condições começou a ser transmitido a dialética de que a punição requeria a redenção dos pecadores, impondo-se a ideia de que era urgente e inadiável obter piedade divina (Bastos, 1997). À comunidade exigia-se a confissão das faltas cometidas e implorarem pelo perdão coletivo, neste contexto, o fanatismo religioso e o desespero criaram práticas religiosas desmedidas, como a criação dos flagelados, o aparecimento de novas ideologias cristãs, heresias, realização de procissões, a perseguição a pessoas inocentes consideradas pecadoras e até mesmo o assassinato de todos os que porventura fossem considerados, por algum motivo, responsáveis pela Peste Negra (Días, 2016). Perante a incerteza, a religião procurou encontrar culpados para a doença, criando ideais irracionais e descabidos, como a teoria difundida por elementos da Igreja, de que os cursos de água foram envenenados pelos judeus, leprosos, bruxas, feiticeiros e muçulmanos, ou seja, todos aqueles que de alguma forma eles consideravam que eram contra os cristãos e a própria Igreja (Toapanta, 2021).

Os membros do clero difundiam a ideia de que o tempo da pandemia era um período retrospetivo das ações do homem, que apesar de existir dor e provação, também era necessário haver a purificação exigida pelo Senhor. O medo que dominava foi monopolizado pela religião para os seus próprios fins, permitindo através do discurso atrair mais pessoas para o cristianismo. No entanto, levou também a sentimentos de desespero, desesperança, angústia, loucura, incitando explosões de violência extrema e heresia coletivas e manipulação psicológica das pessoas (Bastos, 1997). Guy de Chauliac (1300-1368), médico pessoal do papa Clemente VI, corroborou esta perspetiva violenta de perseguição aos judeus, incitada pela Igreja, que acusava este povo como um dos principais responsáveis pela Peste Negra, escrevendo que:

“(...) A causa da elevada mortalidade é desconhecida, mas alguns acreditavam que os judeus tinham envenenado o mundo e por essa razão os mataram (...)."

Chauliac citado por Castiglioni, 1947, p. 420 
Durante a estadia de Chauliac em Avignon, a cidade foi tomada pela peste e a maioria dos médicos fugiu, no entanto, ele permaneceu nas suas funções e tratou os doentes, documentando os sintomas ao pormenor, além de alegar ter sido infetado pela peste e ter sobrevivido com os seus próprios tratamentos (Vieira, 2019).

A crença dos cristãos pela culpabilidade dos judeus residiu na disseminação de mitos antijudaicos desde o ano 1000, os quais reforçavam a ideia do ódio dos judeus pelo cristianismo. Assim sendo, a Igreja tentava influenciar a mentalidade popular transformando os judeus no símbolo do mal e do demónio (Follador, 2016). A maioria da culpa recaiu nos judeus, porque eram despreciados e tinham má reputação (Miguelsanz \& Ramos, 2015) e por isso, tornaram-se alvo de ataques. Alguns cristãos atacaram comunidades judaicas de forma descabida (Fig. 5), por acreditarem que estes eram os responsáveis de lançarem a ira de Deus sobre o povo e pelo envenenado dos poços de água (Miguelsanz \& Ramos, 2015). Foram mortos milhares de judeus, sendo que muitos eram queimados vivos na fogueira e outros forçados a se converterem ao cristianismo. Quanto maior o número de vítimas da peste negra, maior a caça aos judeus, ocorrendo indiscriminadamente sem qualquer aviso, dependendo do estado de espírito de quem os atacavam (Follador, 2016; Balloussier, 2021). A religião remetia a ideologia de que o fogo era purificador de forma a limpar o ambiente (Simoni, 2007).

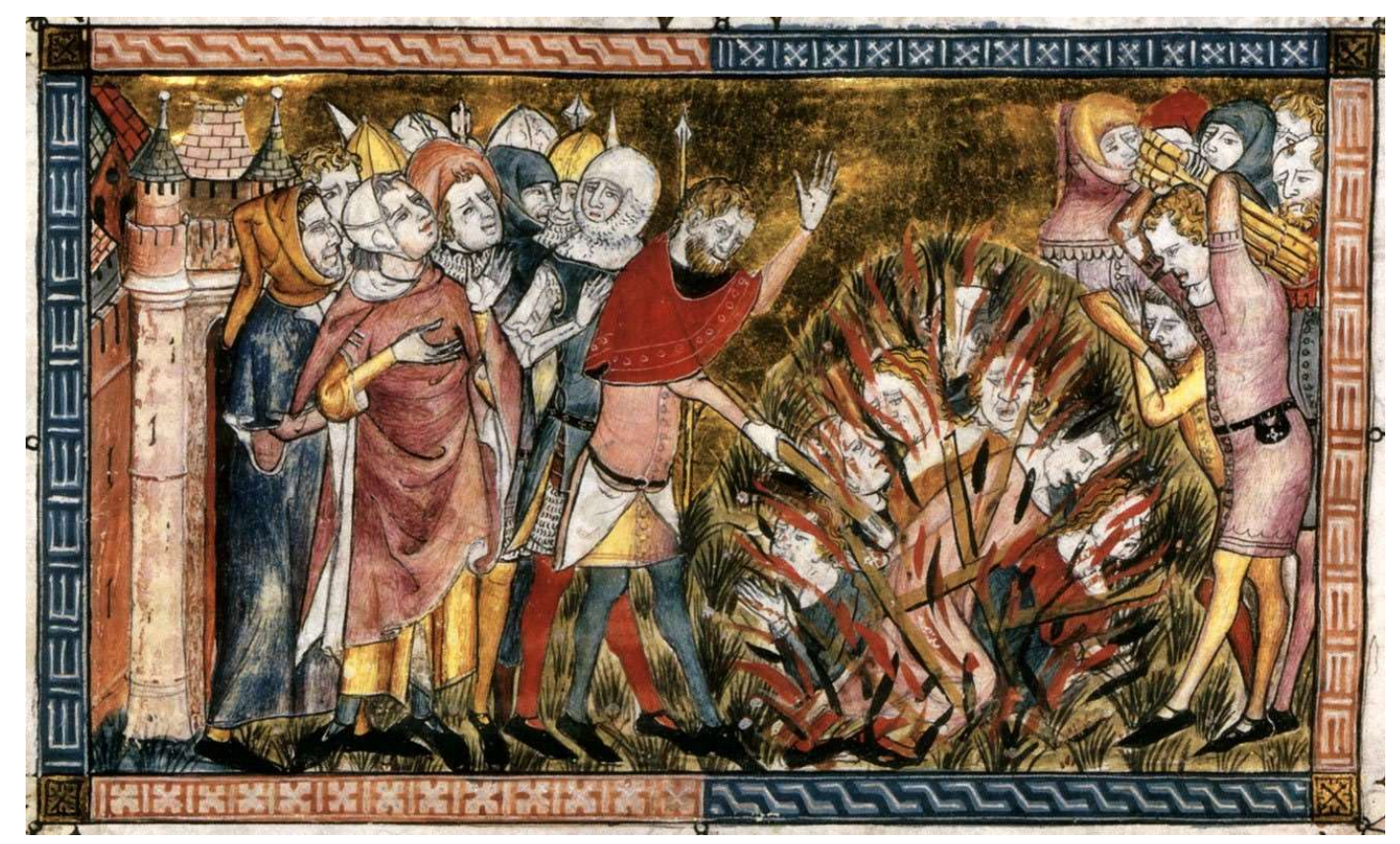

Figura 5 - Massacre aos judeus em Estrasburgo 1349 perseguição e morte na fogueira de mais 2000 judeus durante as perseguições decorrentes da Peste Negra (Antiquitates Flandriae in Royal Library of Belgium manuscript 1376/77). 
Contrariamente às crenças dos cristãos ao acusarem erroneamente os judeus, também eles sucumbiram à pandemia como todos, qualquer pessoa podia contrair a patologia dependendo do seu grau de exposição. A maioria dos médicos que atendiam as populações em várias regiões eram judeus, que lidavam diariamente com os pacientes com peste negra, representando um dos grupos mais suscetíveis à doença devido ao seu contacto contínuo com pacientes infetados. O mesmo aconteceu com os sacerdotes que foi um dos grupos do clero mais afetado pela doença, os quais acabavam infetados ao prestarem as suas funções aos moribundos quando solicitados pelos familiares, acabando o clero por ficar sem párocos para dirigir as eucaristias e darem a extrema unção (Follador, 2016).

A autoflagelação, que consistia numa prática de penitência pública, foi um dos rituais associado à remissão dos pecados. Os flagelados eram um grupo religioso com origem na Itália no século XIII, mas que se difundiu rapidamente pela Europa. Este grupo tinha como objetivo vagar por diferentes cidades em procissão, chicoteando-se em público, o objetivo era fazer penitência para se redimirem dos seus pecados, incitando que mais pessoas os seguissem para atenuar a fúria de Deus. Durante o século XIV, em virtude do grande avanço da Peste Negra, este grupo foi adquirindo cada vez mais adeptos (Miguelsanz \& Ramos, 2015; Bombini, 2020). Como se pode observar numa ilustração da época, os flagelados organizavam procissões públicas durante as quais os homens se encontravam com o torso descoberto, três dele chicoteavam as suas costas, enquanto os outros dois davam um beijo em símbolo de paz. O grupo carregava uma bandeira com a flagelação de Cristo, representando as ações que deviam seguir, como precursor para alcançar o perdão divino (Fig. 6). O objetivo dos flagelados era demonstrar devoção divina, através da oração, da liturgia, da súplica, do arrependimento e do castigo, acreditando-se que as súplicas coletivas poderiam alcançar rapidamente a compaixão do Deus irado (Bastos, 1997).

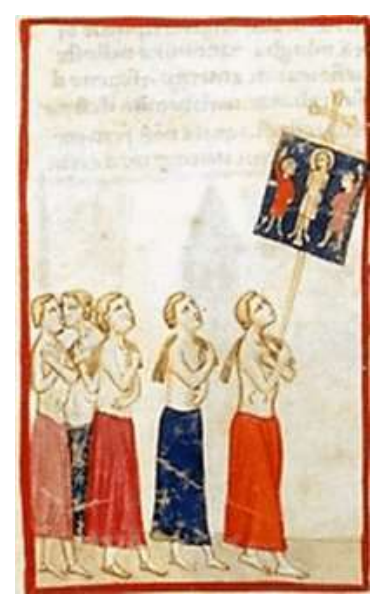

Figura 6 - Os flagelados (Villani, 1348:60). 
A sociedade tinha um grande temor pela morte, pelo que a Igreja começou a difundir a ideia de que era fundamental efetuarem a última luta na sua vida na terra, onde é decidido o futuro da sua alma. Por esta razão começaram a ser efetuadas em todo o mundo inúmeras danças da morte ou danças macabras (Fig. 7) entre 1465 e 1500. Estes eventos eram frequentemente retratados na pintura, na escultura e na literatura da época (Marlow \& Rosa, 2021).

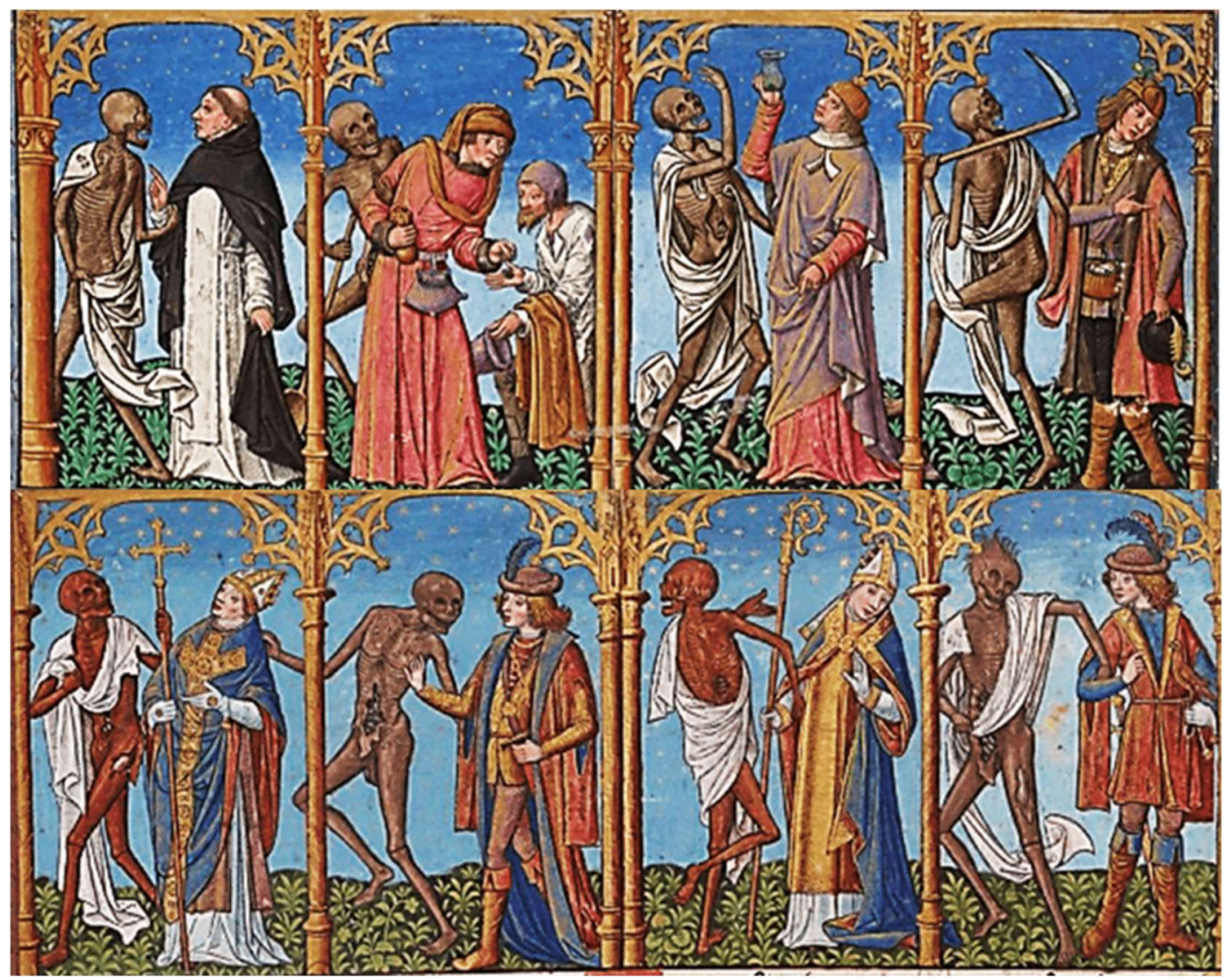

Figura 7 - Danse macabre, Besançon (1491-1492: 17 e 19).

Como a Igreja realçava a importância dos cristãos se redimirem dos seus pecados tentando obter a vida eterna, através da extrema unção, aumentou o número de solicitações dos membros do clero, acabando muitos por morrerem vítimas de peste. Por esta razão, o clero viu-se obrigado a deixar sozinhos muito doentes sem lhes prestar a extrema unção época (Marlow \& Rosa, 2021).

Esta decisão começou alegadamente a criar uma rutura entre as pessoas e a Igreja, porque se era importante se redimirem dos seus pecados, uma vez que era a causa da cólera de Deus, a extrema unção, fazia a diferença entre obterem o caminho do inferno ou atingir o purgatório (Quírico, 2012). Por esta razão, alguns começaram a se sentir abandonados e questionavam a Igreja como instituição, pois até os sacerdotes morriam de peste, então eles estavam definitivamente condenados, 
outros, por seu lado, mesmo vendo a ineficácia da Igreja em suprir as necessidades causadas pela peste, decidiram intensificar a sua devoção desmedida (Días, 2016).

A religião teve um impacto muito grande na população da época. Tentou encontrar culpados para doenças que não conseguia explicar, acabando por serem discriminados, perseguidos e mortos muitos inocentes.

\section{Conclusão}

Este texto permitiu retratar o caos vivido e o sentimento de desespero durante uma das maiores pandemias de sempre, com repercussões negativas no Mundo, que foi a Peste Negra. Por outro lado, esta doença fortaleceu ainda mais o culto e os ideais religiosos.

A Igreja foi responsável por entravar a evolução do conhecimento médico da época, sendo que a cura era obtida por perdão divino, sugerindo-se e praticando-se atos inimagináveis para esse efeito.

Nesta época foram implementados vários rituais cristãos, como procissões, heresias e danças macabras devido à insistência da Igreja no discurso de ser preciso obter a redenção. As pessoas aderiam frequentemente a estes rituais, com uma necessidade obsessiva de aplacar a fúria de Deus, se redimirem pelos pecados para obterem o perdão divino, alcançarem o céu e salvarem a sua alma, a única salvação possível no caos da Peste Negra segundo a religião da época.

É fundamental em todas as áreas do conhecimento científico, para bem da sociedade, que as crenças religiosas infundadas não comprometam a sua evolução, para o bem comum e o acesso a melhores cuidados de saúde.

\section{Referências}

Antiquitates Flandriae in Royal Library of Belgium manuscript 1376/77. Consultado no dia 18/12/2021. https://bit.ly/3HM4GTL

Arrizabalaga, V. (1991). La Peste Negra de 1348: los orígenes de la construcción como enfermedad de una calamidad social. Dynamis: Acta Hispanica ad Medicinae Scientiarumque. Historiam Illustrandam, 11, 073-117. Consultado no dia 15-12-2021. https://bit.ly/3rMWFIW

Balloussier, A. V. (2021). Da peste negra à Covid-19, cultos e missas em pandemias são dilema histórico da humanidade. Consultado no dia 08/12/21. https://bit.ly/3JkFoww

Bastos, M. J. M. (1997). Pecado, castigo e redenção: a peste como elemento do proselitismo cristão (Portugal, séculos XIV/XVI). Tempo, 2(3), 183-205. 
Besançon, J. (1491-1492). Enlumineur. [Danse macabre] : [ou l'Empire de la Mort, sur tous les états de la vie humaine] : [texte imprimé, peinture]. https://bit.ly/3oM4QmR

Boccacio G., (1558), Le Decameron de Jean Bocace Florentin. Consultado na Biblioteca Digital de Paris, no dia 06-12-2021. https://bit.ly/3rMWuNM

Bombini, R. R. (2020). As respostas irlandesas à peste bubônica: entre a medicina e a religião. Brathair, 20(2), 301-319.

Callaway, E. (2011). The Black Death decode, the genome of a 660-year-old bacterium is revealing secrets from one of Europe's darkest chapters. Nature, $478,444-446$

Castiglioni, A. (1947) História da Medicina. São Paulo, Cia. Editora Nacional.

Delumeau, J. (1978). La peur en Occident-XIVe-XVIIIe siècles. Fayard: France.

Di Tura, A. (1348). The Plague in Siena: Italian Chronicle. Consultado no dia 10/12/21. https://bit.ly/3JstD7n

Días, T. F. (2016). A religiosidade sustentada pelo medo: elementos de mudança no imaginário medieval a partir da peste do século XIV. Tempo de Histórias, 29, 39-57.

Escuer, E. F. (2020, marzo 30). Historia de las pandemias - La Peste negra. Nuevatribuna.es. Consultado no dia 8/12/21. https://bit.ly/3oMQEd9

Follador, K. J. (2016). A relação entre a peste negra e os judeus. Revista Vértices, 20, 25-46.

Gottfried, R. S. (1989). La muerte negra - Desastres en la Europa medieval, pp. 91-92. Fondo de Cultura Económica: México.

Gurtner, C. (2020). A peste negra. Consultado no dia 16-12-2021, disponível em https://www.escribacafe.com/post/a-peste-negra

Gusmão, P. (1984). Ideias sobre a peste negra. Humanidades, pp. 27-36. Consultado no dia 15 dezembro de 2021. https://bit.ly/3GSppUY

Jones, L. \& Nevell, R. (2016). Plagued by Doubt and Viral Misinformation: The need for evidence-based use of historical disease images. The Lancet Infectious Diseases, 10, 1-10.

Marlow, S. L. \& Rosa, W. P. (2021). A Peste Negra e o imaginário religioso nas obras de Jean Delumeau. PLURA, Revista de Estudos de Religião, 12(1), 80-98.

Miguelsanz, C. G., Ramos, A. M. (2015). La peste negra. Consultado no dia 12/12/21. https://bit.ly/3rKpm97

Museu Del Prado (2021). O triunfo da morte, Pieter Bruegel (1562). Consultado no dia 12/12/21. https://bit.ly/3sBPqmb 
Pinto, P. (2020). "Grandes males pedem grandes remédios": A peste num sermão do Padre António Vieira. Revista de Estudos de Cultura, 6(17), 21-30.

Quírico, T. (2012): Peste negra escatologia: os efeitos da expectativa da morte sobre a religiosidade do século XIV. Mirabilia: 135-155.

Quírico, T. (2021). Imagem e devoção em tempos de pandemia: apontamentos sobre a Peste Negra e a religiosidade cristã no fim da Idade Média. Concinnitas, 22(40), 187-209.

Sánchez-David, C. E. (2008). La muerte negra, "el avance de la peste". Revista Med, 16(1): 133-135.

Silva, M. L., Obara, F. W. H., Avila, R. N. P. (2018). Uma pesquisa sobre a peste negra. Anais do $54^{\circ}$ Congresso da Sociedade Brasileira de Medicina Tropical. Consultado no 10 de dezembro de 2021. https://bit.ly/3oJh27Y

Simoni, K. (2007). De peste e literatura: imagens do Decameron de Giovanni Boccacio. Anuário de literatura umbral, pp. 31-40.

Toapanta, H. G. G. (2021). Pandemias en la Historia: La peste negra y la gripe española, covid-19 y crisis capitalista. Revista de Ciências Sociales y Humanidades, CHAKIÑAN, 14,130-145.

Vieira, M. (2019). Guy de Chauliac (1300-1368). Unicentro Paraná - GPET Física Unicentro. Consultado no dia 13/12/2021, https://bit.ly/3sxWNLv

Villani, G. (1348). Die Nuova Cronica des Giovanni Villani tradução Verena Gebhard. (2007). Consultado no dia 16-12-2021. https://bit.ly/3rMGIT6 